\title{
Two Influential Concepts: Socialist Legality and Constitutional Identity and Their Impact on the Independence of the Judiciary
}

\author{
Fruzsina Gardos-Orosz ${ }^{1}$ \\ ${ }^{1}$ Center for Social Sciences, ELTE Law School, Budapest, Hungary \\ Corresponding author: orosz.fruzsina@tk.hu
}

(Received 29 September 2021; accepted 29 September 2021)

\begin{abstract}
In this Article, I suggest considering linkages of a theoretical, and continuities of a sociological nature between on the one hand, the concept and the practical use of socialist legality in Socialist Hungary-with particular regard to the period following the judicial reform of 1954-and on the other hand, the concept of constitutional identity as it has developed in the Fundamental Law in Hungary, with particular regard to the period since the 2011 judicial reform. The Article highlights surprising similarities in the politically determined legislative intention in these two periods to form embracing, quasi legal concepts, which in themselves seem to differ fundamentally, although the similarities in their nature and in the specific constitutional practice are attention-grabbing. The interpretation of the role of state institutions, and especially the judicial role, lead one to think that despite the explicit rejection of the Socialist era in Article U) of the Fundamental Law in Hungary, the new constitutional regime has familiar attitudes to the understanding of the rule of law and the role of the judiciary in promoting the enforcement of the new, supra legal concepts of a transformative nature, which, however, are filled in with the ruling political ideology, whether it be socialist legality or national constitutional identity.
\end{abstract}

Keywords: Constitutional identity; socialist legality; judicial independence; socialist judiciary; fundamental Law

Fruzsina Gardos-Orosz is a senior research fellow of the Institute for Legal Studies, Center for Social Sciences and is also associate professor in constitutional law at the Law Faculty of ELTE University. Her research interests focus on the application of fundamental rights in private relations, constitutional justice and doctrinal issues of human rights protection. The work was supported also by 129018 program on Resilience of the Hungarian legal system funded by the National Research Development and Innovation Office and European Union's Horizon 2020 research and innovation program under grant agreement No. 822590, DEMOS.

(C) The Author(s) 2021. Published by Cambridge University Press on behalf of the German Law Journal. This is an Open Access article, distributed under the terms of the Creative Commons Attribution licence (https://creativecommons.org/licenses/by/4.0/), which permits unrestricted re-use, distribution, and reproduction in any medium, provided the original work is properly cited. 


\section{A. Introduction - Contemporary Hungary (2010-2020) and the Socialist State (1949-1989)}

The constitutional system and democracy of Hungary is frequently characterized as a "populist," "illiberal," "hybrid,"3 or "semi-authoritarian" regime. $^{5}$ The Fundamental Law of Hungary entered into force on January 1, 2012 and was adopted by the two-thirds constitution-making political majority of the Fidesz-Christian Democrat party coalition. Article U) of the Fundamental Law states that:

(1) The state structure based on the rule of law, established by the will of the nation through the first free elections held in 1990, and the previous communist dictatorship ${ }^{6}$ are incompatible. The Hungarian Socialist Workers' Party and its legal predecessors and the other political organizations established to serve them in the spirit of communist ideology were criminal organizations, and their leaders shall have responsibility without a statute of limitations for a) maintaining and directing an oppressive regime, violating the law and betraying the nation ....?

I will argue here that although the new Hungarian constitution rejects the Socialist period, certain attitudes in legal policy live on, ${ }^{8}$ and similarities appear, if not primarily in the legal texts, at least in the conceptual framework. In this Article, I will focus on the influence of significant political-in practice supra-legal-concepts on the interpretation of law introduced by one political power unilaterally. I argue that in regimes with centralized state power, over time these concepts begin to influence not only the specific legal design, but the judicial interpretive practice as well. I will explain how the transformative nature and value of these concepts are, for many of us, still familiar from socialism.

The concept of "socialist legality" gave normative but flexible content to a particular understanding of the law and laid out the optimal space for the independence in legal interpretation for the judiciary by formulating an uncertain conceptual framework. Being a familiar concept in Hungary, it is easier to understand "constitutional identity" as introduced into Hungarian law in 2016 and assess what it contributes to the legal system through the slow transformation of the law's interpretation, application, and judge's attitudes themselves.

I will examine this hypothesis after the introduction of the concept of socialist legality by Prime Minister Imre Nagy following Stalin's death, with particular regard to the judiciary and judicial

\footnotetext{
${ }^{1}$ Gábor Halmai, A Coup Against Constitutional Democracy: The Case of Hungary, in Constitutional DemOCRACY IN Crisis? 243 (Mark A. Graber et al. eds., 2018); Neil Walker, Populism and Constitutional Tension, 17 ICON 515, 521, 524 (2019); Thèo Fournier, From Rhetoric to Action, a Constitutional Analysis of Populism, 20 GERMAN L.J. 362, 362-81 (2019); Bojan Bugarič, Central Europe's Descent into Autocracy: A Constitutional Analysis of Authoritarian Populism, 17 ICON 597, 597-616 (2019).

${ }^{2}$ Cesare Pinelli, Populism and Illiberal Democracies: The Case of Hungary, in Challenges and Pitfalls In THE Recent Hungarian Constitutional Development: Discussing the New Fundamental Law of Hungary 211-19 (Zoltán Szente et al. eds., 2015); Tímea Drinóczi \& Agnieszka Bień-Kacała, Illiberal Constitutionalism: The Case of Hungary and Poland, 20 Ger. L.J. 1140, 1140-66 (2019); Renáta Uitz, Can You Tell When an Illiberal Democracy is in the Making? 13 ICON 279, 279-300 (2015).

${ }^{3}$ András Bozóki \& Dániel Hegedűs, An Externally Constrained Hybrid Regime: Hungary in the European Union, 25 Democratization 1173, 1173-1189 (2019).

${ }^{4}$ Bojan Bugarič \& Tom Ginsburg, The Assault on Postcommunist Courts, 27 J. DeMOCRACY 69, 70 (2016); Bojan Bugaric \& Alenka Kuhelj, Varieties of Populism in Europe: Is the Rule of Law in Danger?, 10 Hague J. Rule LaW 21, 25 (2018).

${ }^{5}$ Read more about this phenomenon in Zoltán Szente, Populism and Populist Constitutionalism, in Populist CHALlEnges to Constitutional Interpretation in Europe and Beyond (Fruzsina Gárdos-Orosz \& Zoltán Szente, eds., 2021).

${ }^{6} \mathrm{I}$ use the words communist and socialist interchangeably in this text from a doctrinal point of view. I follow in my choice the usual rhetorical context in Hungary.

${ }^{7}$ Article U) of the Fundamental Law of Hungary.

${ }^{8}$ Herbert Küpper, Közép-Kelet Európai és poszt szocialista jogrendszerek, in INTERNET JURISPRUDENCE ENCYCLOPEDIA 7-10 (Balázs Fekete ed., 2017).
} 
decision-making environment created by the Act of 1954 on the court system, which was in force until 1972. In 1972, a new era started with the constitutional revision and the new act on the judiciary. To match socialist legality with constitutional identity, I will continue the story from 2011 when the two-thirds Fidesz-Christian Democrat parliamentary majority introduced judicial reform and adopted the new constitution, the Fundamental Law and the concept of constitutional identity appeared in 2016.

This Article proceeds as follows. Section A explains socialist legality and the transformation of the rule of law after 1954 by using the example of the regulation of the judiciary. In Section B, I will describe the recent changes in these issues in Hungary since 2011. Section C, the comparative conclusion, explains the similarities between the two periods. My inquiry addresses the similarly specific supra and quasi legal character of the two concepts and their possible affect on independence-related judicial attitudes in the interpretation and application of the law.

\section{B. Socialism and Forms of Independence ${ }^{9}$}

\section{The Concept of Socialist Legality}

The concept of socialist legality first appeared in Hungary in the 1950s, during Imre Nagy's premiership. Nagy was appointed prime minister of Hungary in 1953, in a period of uncertainty after Stalin's death. He was a devout communist who was not ready to give up absolute power, but at the same time, he opposed the Stalinist politics of his predecessor, Mátyás Rákosi, and he did not want his people to live in constant fear and terror.

To make people understand that times were changing, Nagy promised the country in 1953 that he was going to restore socialist legality. ${ }^{10}$ In Nagy's interpretation, socialist legality meant that power is exercised in harmony with socialist laws. This was a specific understanding of the rule of law. Consequently, he did not object to the Constitution and the laws introduced by the communist regime, he simply thought that Rákosi had not abided by them. Furthermore, he urged his government to start codification in areas classically viewed as having constitutional relevance. ${ }^{11}$ It is no coincidence that the regulations analyzed later in this Article-the act on the organization of the courts and the decree on public prosecution-both entered into force in this period. This was not unique as a tendency in the Socialist part of Europe. ${ }^{12}$

After his involvement in the Revolution of 1956, Imre Nagy was killed by his former comrades. However, the concept of socialist legality did not die with him. Instead, it remained in use both by those who had participated actively in Nagy's liquidation and the revolutionaries. ${ }^{13}$

In the 1960s, the term gained a new meaning thanks to the chief legal theorist of the Kádár regime, Imre Szabó. He examined the Western idea of the rule of law and condemned those who thought that socialism could be built in such a system. ${ }^{14} \mathrm{He}$ emphasized that the rule of law seemingly served everyone's interests, but in fact, it only suited the enemies of the working class. This is why a socialist state had to create a legal order which worked by the same logic, but which protected the needs of the proletariat. ${ }^{15}$ Szabó called this system socialist legality and argued that it

\footnotetext{
${ }^{9} \mathrm{I}$ am grateful in this part for the research assistance of Domonkos Polonyi, and especially for the preparation of points regarding socialist legality. Furthermore, I would like to thank András Bragyova, former judge of the Constitutional Court and my respected distinguished professor at the Institute for Legal Studies, for helping my research with literature and with his precious comments. His crushing loss is felt in this Article.

${ }^{10}$ Prime Minister Imre Nagy, Speech in the Parliament (July 4, 1953).

${ }^{11}$ Ferenc Glatz, A desztalinizáció első hulláma Magyarországon: Nagy Imre kontra Rákosi Mátyás, 1953-1956, 28 HISTÓRIA 50, 52 (2006).

${ }^{12}$ Hugh W. Babb \& John N. Hazard, Soviet Legal Philosophy (John N. Hazard ed., 1951); René David \& John E.C. Brierley, Major Legal Systems in the World Today: An Introduction to the Comparative Study of LaW (1968).

${ }^{13}$ Imre Markója, Forradalmi diktatúra-szocialista törvényesség, 2 TÁRSADALMI SzEMLE, 17, $21-23$ (1957).

${ }^{14}$ Imre SZABÓ, A SZOCIAlista Jog 100-03 (Bèla Popovics ed., 1963).

${ }^{15} I d$. at $82-88$.
} 
could not be interpreted in a purely formal way. In his eyes, socialist legality was superior to the rule of law simply because its purpose was better. Nonetheless, as this Article will illustrate through the example of the independence of the judges, the criteria of socialist legality were frequently infringed upon right up until the end of the Kádár era.

The first judicial act based on socialist legality that entered into force in 1954 rejected the Rákosi dictatorship, the previous uncertainty in political actions not governed by law, and the arbitrariness of the judiciary. ${ }^{16}$ This Act emphasized ${ }^{17}$ that Article 41 (2) of Act XX of 1949 on the Constitution of the People's Republic's declares: "In the Hungarian People's Republic the judges are independent and subject only to the law." In this period, the administration of the judiciary was sufficiently well-established to serve the independence of the judiciary and the judges, although as an element in the Constitution, based on the unity of power.

According to Imre Szabó, the action of the State must embrace the will of the ruling class, as represented by the ruling class's authentic representative, the Party. ${ }^{18}$ The Party formulates the intention, but its manifestation becomes evident in state action. Socialist legality is about this interaction involving the constructed will of the people, the Party, and the State and its legal action. The general will, the source of the state action, is abstract; it is impossible to ask concrete questions about it because to do so would give a reason to contest this will as the source of the party's position and the power of the state. While the reason for the codification of the rules is purely societal and economic in a bourgeois state, in a socialist state it is necessary in order to satisfy the ruling class's need to provide legal certainty and effective central administration of the state. ${ }^{19}$ Szabó also talks about the importance of an integrated legal policy. This integrated legal policy is determined by the Party — as are general policies - in order to provide legal security. This concept requires that the law be interpreted and applied according to the general and judicial policies of the Party. The concept of socialist legality as a normative but quasi and supra legal concept makes the law instrumental ${ }^{20}$ because this particular understanding of the rule of law means that the law's aim is not to establish the rule of law, but the rule of the Party. ${ }^{21}$

\section{The Socialist Judiciary and its Administration}

The judiciary has traditionally been regarded as an independent branch of state power in Hungary since courts were first separated from the executive in the second half of the 19th century. ${ }^{22}$ The history of the administration of justice between 1949 and 1990 was not straightforward and uninterrupted but, according to Szente's study in this Special Issue, it can nonetheless be divided into several stages. Between 1948 and 1950, the legal and human resources of the proletarian dictatorship were established. This period was followed by a period of totalitarian dictatorship until 1953, under which the courts were instruments of political repression. The "new phase" between June 1953 and April 1955 sought to limit the dictatorship's infringements within the framework of socialist legality, while after the suppression of the 1956 revolution until 1962, the courts again became the instruments of repressive action against the revolutionaries. After the consolidation of the Kádár regime, especially after the constitutional amendment of 1972, the judiciary was consolidated and judicial independence, within the limits of the socialist

\footnotetext{
${ }^{16}$ See Nagy, supra note 10.

${ }^{17} 1954$. évi II. törvény a Magyar Népköztársaság bírósági szervezetéről (Act II of 1954 on the court system of the Hungarian People's Republic) (Hung.).

${ }^{18}$ Péter Szilágyi, Szabó Imre szocialista normativizmusa, 4 Jogelméleti Szemle 23. (2003).

${ }^{19}$ Id. at $23-32$.

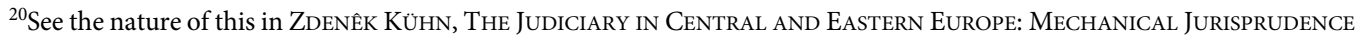
in TRANSFormation (2011).

${ }^{21} I d$.

${ }^{22}$ See the summary by Zoltán Szente, Stepping Into the Same River Twice? Judicial Independence in Old and New Authoritarianism, in this Special Issue.
} 
authoritarianism, was strengthened. In the late 1980s, the courts became more and more independent of the control of the Communist Party. ${ }^{23}$

The literature explains that before the Act II of 1954 on the court system of the Hungarian People's Republic, the applicable law on the courts was mainly the law that had been in force in Hungary before the Second World War. ${ }^{24}$ However, from the point of view of our research, it is not worth analyzing this in detail because in the Rákosi period of communist dictatorship, the courts did not operate lawfully, but rather arbitrarily. People's courts and revolutionary justice were established with a single-instance jurisdiction, and these courts worked entirely according to the rules of a dictatorship. ${ }^{25}$ The period when socialist legality prevailed was a break with the previous dictatorship.

It is interesting to note that the 1956 Revolution and the related judicial proceedings were only partial exemptions from the general rule of consolidated socialist legality because the courts continued their operation almost without interruption in civil and economic matters. ${ }^{26}$ In sum, the period before 1954 and the jurisprudence related to the 1956 Revolution must be distinguished from the socialist legality achievements in jurisprudence as codified primarily in Act XX of 1949 on the Constitution and Act II of 1954 on the court system. ${ }^{27}$ Nevertheless, 1972 was another turning point, when Act IV on the courts was passed according to the general revision of the Constitution. This act brought essential changes in the independence of the courts in a positive direction. ${ }^{28}$ In this period, the judiciary's independence was soon interpreted at that time very similarly to the "Western bourgeois concept." 29

\section{Socialist Legality and Judicial Independence in Books}

Judicial administration as a broad concept is everything that happens outside the courtroom but is connected to judicial activity. According to Act XX of 1949 on the Constitution and Act II of 1954 on the court system, the Minister of Justice, the courts themselves, the representative bodies of the people at different levels-local and territorial councils and the Parliament-and the Public Prosecutor took part in the administration of the judiciary. The proper administration of the judiciary according to the very contemporary language of the act guarantees an independent and competent judicial service.

In this section, dealing with the formal administration of the judiciary, we must, however, say a few words about the role of the Public Prosecutor. Although this is not strictly related to the administration, it is vital for a general assessment of the legal environment of the daily operation of the judiciary. The Public Prosecutor's task in the Hungarian People's Republic was the control of the legality of criminal justice and its implementation. The Public Prosecutor was responsible for controlling the legality of the ministries and local authorities concerning regulations, ordinances, and other dispositions. The Prosecutor had the right to initiate any civil procedures apart from the criminal procedures and the right to intervene in any part of the process on behalf of any of the parties. ${ }^{30}$

\footnotetext{
${ }^{23} I d$.

${ }^{24}$ Especially in English: AtTila RÁcZ, Courts And Tribunals: A COMParative STUdy 49 (Miklos Zehery trans., 1980). For more detail about the transformation until 1954 in Hungarian, see LÁSZLÓ NÉVAI, TÖRVÉNYKEZÉSI SZERVEZETI JOG 97-106 (Felsőoktatási Jegyzetellátó Vállalat ed., 1961).

${ }^{25}$ Attila Horváth, A Magyar bírósági szervezet története a szovjet típusú diktatúra idején, 1-2 JOGTÖRTÉNETI SzEMLE 128, 128 (2017).

${ }^{26}$ GÉZA SZÉnÁsi, A tÖRVÉNYESSÉG ÖRHELYÉn (Ròbert Pogány ed., 1958).

${ }^{27}$ Gyula EÖRSI, Legal System AND Administration OF Justice IN Hungary 56 (Hungarian Association for the United Nations 1958).

${ }^{28}$ Miklós Kengyel, A bírói hatalom és a felek rendelkezési joga A POlgÁri Perben 210-11 (Gábor Luca \& Mezey Barna eds., 2003).

${ }^{29} I d$.

${ }^{30}$ LÁsZLó NÉvaI, supra note 24, at 184-85. See the later development in: Az ÜGYÉSZI TÖRVÉNYKEZÉSI JOG ALAPVETÖ SZABÁLYAI 265-90 (1974).
} 
According to the act, the heads of the first instance courts, the heads of the second instance courts, and the Supreme Court—as judicial bodies—-had a say in court administration matters. ${ }^{31}$ Furthermore, according to the act on the court system, the Supreme Court was responsible for the administration, control over the operation, and jurisprudence of all courts. The head of the Supreme Court directed the Supreme Court and dealt with the distribution and treatment of the petitions in due time. The head of the Supreme Court decided on the appointment of judges in the different divisions of criminal law and civil law. The head of the Supreme Court had the right to take any of the court cases from the lower courts and proceed with the trial before the Supreme Court. According to Act II of 1954, the heads of the regional and local courts had similar tools. In these times, there was no self-government of the court system. The appointment, the removal, and the discipline of judges was much more straightforward and hierarchical, with far fewer guarantees than nowadays.

Article 39 of the 1949 Constitution stated that in the Hungarian People's Republic all positions in the courts are filled by election. Judges can be recalled from their positions. The election of judges is not specified in the Constitution, except for the election of the Supreme Court judges by the Parliament, but it is clear that elected judges are responsible to the people and can be recalled under certain circumstances.

Judges and lay judges — it was a joint adjudication system with social, lay participation ${ }^{32}$ — could be any Hungarian citizen with a clean record who had the right to vote and was over twenty-three years old. ${ }^{33}$ Judges and lay judges were mentioned together in the text of the law; according to the legal analysis of this period, the lay element did not play a significant role, which means that the judicial decisions were taken under the guidance of the professionals. Becoming a judge in this period was not a very popular vocational choice, ${ }^{34}$ and the prestige and remuneration of the individual judge was not very high in the Budapest law schools, such that only a few students were keen on becoming a judge. ${ }^{35}$ In the countryside, the situation was slightly different because being a judge was a prestigious job. Therefore, it mattered a good deal for the judge which city, bigger or smaller, accepted his or her services. There was competition to be appointed to a bigger, more cosmopolitan town, rather than a remote location, where the quality of life was completely different. According to the rules, nobody could be removed from their place of service without their consent. Professional judges could not conduct any other non-academic or artistic professions ${ }^{36}$ in order to preserve their independence, and incompatibility rules were formulated in a markedly standard way. The general regulations on appointments in Act II of 1954 on the court system went as follows: ${ }^{37}$ The heads of the local first instance courts and the local councils elected professional and lay judges for three years upon the nomination of the Minister of Justice. The county councils elected the head of the county courts and their judges and lay judges for three years upon the proposal of the Minister of Justice. According to Article 39 of the Constitution, the head of the Supreme Court, deputies, judges, and lay judges were elected by the Parliament for five years.

Although the relevant paragraph of this law does not mention the nomination procedure, this nomination was also made by the Minister of Justice. According to the 25/1963 NET (Presidential Council of the People's Republic / the body functioning as head of State) resolution point 2, the

\footnotetext{
${ }^{31} 1954$. évi II. törvény a Magyar Népköztársaság bírósági szervezetéről (Act II of 1954 on the court system of the Hungarian People's Republic) (Hung.).

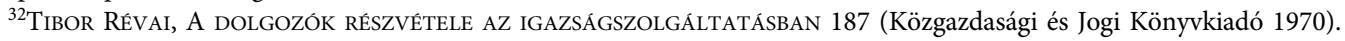

${ }^{33} 1954$. évi II. törvény a Magyar Népköztársaság bírósági szervezetéről (Act II of 1954 on the court system of the Hungarian People's Republic) (Hung.).

${ }^{34}$ Ota Ulc, The Judge in a Communist State: A View from Within Athens (1972).

${ }^{35}$ It was even less prestigious, though, to become a prosecutor, see ENDRE Bócz, NÉGY ÉvTIZEd AZ ÜGYéSzSÉGEN: PÁlYÁM EMLÉKEZETE 30-31 (2010).

${ }^{36} 1954$. évi II. törvény a Magyar Népköztársaság bírósági szervezetéről (Act II of 1954 on the court system of the Hungarian People’s Republic) (Hung.).

${ }^{37} I d$.
} 
Council of Ministers was responsible for the appointment of the heads of the local and regional courts and all other judges were appointed by the Minister of Justice.

As to the general rules on removal and the disciplinary measures in Act II of 1954, the following rules applied. Professional and lay judges could be recalled before the termination of their office if they had committed a crime, carried out their tasks in a negligent manner, or if their conduct otherwise violated the authority of the people's justice system. ${ }^{38}$ The electoral body could recall judges and lay judges upon the initiative of the Minister of Justice. The prosecution and removal of a judge was only possible upon the initiative of the Public Prosecutor with the consent of the President's Council of the Hungarian People's Republic. The Minister of Justice was responsible for the administration of the judiciary. In this period, there were no detailed rules on the qualification or measurement of judicial work. The number of appeals was, however, a good indicator in this period, as it appears in literature, ${ }^{39}$ but no other specific, generally indicated control mechanism existed.

The Act on the court system ${ }^{40}$ included the requirement that judges must be exempt from criticism. They must complete their tasks with sincerity and due attention. If a judge was negligent or irresponsible, he or she would be unworthy of the authority of the Hungarian People's Republic or its justice system, and this would constitute an offense against the discipline. In cases involving heads of courts and professional judges, the disciplinary procedures were conducted by the disciplinary committees operating at the county courts, the Budapest Court included, and the Supreme Court. There was the right to appeal against such a ruling, and the Public Prosecutor and the Minister of Justice could also raise a request for appeal. Even after the decision had come into force, it was still possible for these bodies to initiate a review of the legality of the decision. The consequence of the disciplinary procedure could be a charge, censure, severe reprimand, and finally, the initiation of the judge's recall. The Committee of Ministers formulated the detailed rules of the disciplinary procedure according to the law.

I will argue in the following section that within the above legal framework the influence of the concept of socialist legality led to a particular understanding of the rule of law and judicial independence. Also, I will argue that instead of legality in the strict sense, room was allowed for the ruling political ideology in the application of rules.

\section{The Practice of Judicial Administration}

In real life, I suggest that the system of judicial administration consisted of different types of administration in both formal, statutory and regulatory, and informal senses. The informal impacts were to correct and guide judicial work to ensure a better enforcement of socialist legality. Any correction in the application of positive law was entrusted to the political power and other state institutions that were openly more connected to the party. ${ }^{41}$ Judicial policy in the name of socialist legality was created by and large by the State, which was ruled by the Party, but civil matters, for instance, were not coordinated directly, and therefore the judges were not under direct pressure. The situation was somewhat different in criminal matters because there could be sensitive cases where the previous central opinion on the case was submitted to the judge. ${ }^{42}$ Economic cases were not judged by the ordinary courts in this period, and most civil law matters, such as marriage disputes, were adjudicated without the need for political influence. It was only in some criminal cases that political influence appeared. Everyone who became a criminal judge in Hungary was

\footnotetext{
${ }^{38} I d$.

${ }^{39}$ László Névai, A magyar bírósági szervezet fejlődése a felszabadulás óta, 4 JoGTUDOMÁNYI KÖZLÖNy 210, 210-23 (1960).

${ }^{40} 1954$. évi II. törvény a Magyar Népköztársaság bírósági szervezetéről (Act II of 1954 on the court system of the Hungarian People's Republic) (Hung.).

${ }^{41}$ The representative bodies did not have much real and effective influence in the administration of the courts; they just voted automatically according to the initiative.

${ }^{42}$ Zsolt Zádori, Titkos pártszerv tartotta rövid pórázon a bíróságokat, HVG.HU (Jan. 14, 2008), https://hvg.hu/itthon/ 20080114_koordinacios_bizottsag_mszmp_birosag.
} 
clearly aware that this influence had to be accepted as the state power was unique and its goals were formulated primarily by the political branches of state power. The influence and the pressure, for example, that the interpretation of one or the other legal rule should be transformed according to the broader state goals of socialist legality articulated by the centralized party state, could be made explicit by the judicial administration. I have collected in the table below the formal and the informal sources of authority used to create an atmosphere restricting a judicial decision.

\begin{tabular}{lcccc}
\hline $\begin{array}{l}\text { Formal } \\
\text { administration }\end{array}$ & $\begin{array}{c}\text { Formal } \\
\text { administration }\end{array}$ & $\begin{array}{c}\text { Informal } \\
\text { administration }\end{array}$ & $\begin{array}{c}\text { Informal } \\
\text { administration }\end{array}$ & $\begin{array}{c}\text { Informal } \\
\text { administration }\end{array}$ \\
\hline $\begin{array}{l}\text { The Ministry } \\
\text { of Justice }\end{array}$ & $\begin{array}{c}\text { Heads of the local } \\
\text { and territorial } \\
\text { courts and the } \\
\text { Supreme Court }\end{array}$ & $\begin{array}{c}\text { The Ministry of } \\
\text { Justice }\end{array}$ & $\begin{array}{c}\text { The Party (MDP, } \\
\text { MSZMP), }\end{array}$ & $\begin{array}{c}\text { The Public } \\
\text { Prosecutor } \\
\text { primarily } \\
\end{array}$ \\
& & through the & \\
& & Committee of \\
& & Administration \\
& & creating \\
& & principles on \\
& & judicial policy & \\
& & &
\end{tabular}

\section{Public Prosecutor}

According to the literature, ${ }^{43}$ the Public Prosecutor, as the voice of the supreme decision-makers, had a significant influence on the judiciary's operation not only in criminal cases but also in some civil law disputes where he had the right to almost unlimited intervention. It was also possible for the Public Prosecutor to take the case or start a disciplinary procedure against a judge. Therefore, while the administration's technical aspects were governed mostly by the Ministry of Justice, the Public Prosecutor and his office safeguarded legality in substantive and procedural matters. As I have noted above, the Public Prosecutor's Office-the structured operation of the Public Prosecutor-was reorganized and re-established in 1954, but it became important as the supervisor of the courts' legality. Interestingly, the Prosecutor's status was the same as that of the judge, and their judicial disciplinary committees were identical. ${ }^{44}$

The head of the public prosecution was also elected by the Parliament and could participate in Government sessions, but was not instructed directly by the Minister of Justice or by the Party. ${ }^{45}$ He was a member of the so-called Coordination Committee of the Administration of Justice, a very important political institution that consisted of the Head of the Supreme Court, the Public Prosecutor, the Minister of Justice, and the head of the Department of Administration of the Central Committee, and the Minister of Internal Affairs. This committee was secret and informal and was the supreme body of the judicial administration and coordinated judicial policy. ${ }^{46}$

\section{Heads of the Courts}

In regard to the pressure put on the judges, the "Hausrecht" always played a role. The rooms, equipment, and the physical location of the service were always important tools used to influence the judges, especially when the system was not wealthy. As the heads of the courts had the right to administer the court, it was necessary to have political consent from the head of the courts on the

\footnotetext{
${ }^{43}$ LÁSZLÓ NÉVAI, TÖRVÉNYKEZÉSI SZERVEZETI JOG at 183-86.

${ }^{44} I d$. at $211-13$.

${ }^{45} 1953$. évi XIII. törvényerejű rendelet a Magyar Népköztársaság ügyészségéről (Decree with Statutory Force 13 of 1953 on the Public Prosecution of the Hungarian People's Republic) (Hung.).

${ }^{46}$ Béla Révész, A pártállami időszak ismeretlen hatalmi testülete: a Koordinációs Bizottság 1957-1988, 76 ACTA UNIVERSITATIS SZEGEDIENSIS 387, 393-94 (2014).
} 
local level as well, although at very small courts it was a challenge to find professional judges that would be acceptable to the Nomenklatura. ${ }^{47}$

Before 1972 it was possible to become a professional judge without a legal qualification, but in practice, between 1954 and 1972, most professional judges had a law degree. It was only the 1972 reform which introduced this as a requirement.

One major tool of influence exercised by the heads of the courts was the distribution of cases. As there was no rule for the distribution, the most important or sensitive cases could go to those judges who had the right place in the Nomenklatura, or were otherwise reliable. Later, in the 1980 s, there was a protocol for the distribution of cases, but this could also be overruled in important and sensitive cases. ${ }^{48}$

\section{The Ministry of Justice}

According to the democratic principle, even if the judges were elected by one of the State's representative bodies, they were appointed by the Minister of Justice to their place of service, and the Minister also decided on which division, civil or criminal, they would operate in, even if the law stated otherwise. It was also possible for someone to be appointed to one particular court, for instance, the transport court, when it existed. ${ }^{49}$

\section{The Party and the Coordinating Committee}

Of the criminal judges, the majority became Communist Party members, while for the civil law judges Party membership was probably not so important. In the most important cases, discipline and pressure could also come from the Party in the form of party discipline. Although the collected data does not show a significant number of these procedures, as judges were members of the Party, it was also a pressure that might have affected their behavior and attitudes in the interpretation of the law. The Nomenklatura oversaw the human resources politics of the Party, and it was evident that everyone had a ranking in this system..$^{50}$

According to the documents discovered by Béla Révész in 2010, the Coordinating Committee was the center of the informal administration. They decided mostly in questions of judicial policy and individual cases when it was in the party's interest. The Committee probably worked from 1957 to 1988, but the related documents were discovered only for the period from 1965 onwards. This secret committee was mentioned several times by the leaders of the Party and the State as a reference point in the judicial administration. ${ }^{51}$

\section{The Era of Illiberal Democracy: 2010-2020}

Hungary is categorized as a Member State of the European Union (EU) ruled by a populist Government. ${ }^{52}$ The Hungarian government is qualified as populist because, according to the

\footnotetext{
${ }^{47}$ Nomenklatura is the circle of leading officials in the partystate. OTTÓ BIHARI, Államjog (1964).

${ }^{48}$ Zoltán FleCK, JogSZOlgâlatATó MECHANIZMUSOK AZ ÁlLAMSZOCIALIZMUSBAN: TotALITARIANIZMUS ELMÉLETEK ÉS A MAGYARORSZÁGI SZOCIALIZMUS (2001).

${ }^{49}$ Attila Rácz, Az igazságszolgáltatási tevékenység és a birói szervezet alkotmányjogi alapjai, in András Holló, Ferenc Kelemen: Alkotmányjog II. Chapter 6.

${ }^{50}$ Find further literature at Bibliográfia Tematikus MagyarorsZáG BírósÁGAI, https://birosag.hu/birosagtortenet/ bibliografia/bibliografia-tematikus\#section-305 (last visited Aug. 22, 2021).

${ }^{51}$ Révész, supra note 46, at 392-93.

${ }^{52}$ For example, Andrew Arato, How We Got Here? Transition Failures, Their Causes and the Populist Interest in the Constitution, 45 PHIL. \& Soc. CRITICISM 1106, 1108 (2019); Bojan Bugaric, The Two Faces of Populism: Between Authoritarian and Democratic Populism, 20 German L.J. 390, 392-93 (2019); Bojan Bugaric \& Alenka Kuhelj, Varieties of Populism in Europe: Is the Rule of Law in Danger?, 10 Hague J. Rule Law 21, 22 (2018); Manuel Anselmi, POPULISM: AN INTRODUCTION 87 (2018).
} 
scholarship of political science, many elements of the definition of populism fit with the Hungarian political system. Furthermore, the Government has a two-thirds constitution-making majority in the Parliament; therefore, Hungary's constitutionalism since 2010 has been formed and transformed by the ruling political majority alone. As political goals can easily be transformed into constitutional changes and the constitutional environment adapts to the political agenda immediately, the scholarly criteria of so-called populist, or as it is otherwise known illiberal constitutionalism, can be observed in Hungary. ${ }^{53}$

\section{The 1989 Democratic Transition and the Contemporary Notion of Judicial Independence}

Judging cases is a monopoly of the ordinary judiciary in contemporary Hungary. ${ }^{54}$ During the democratic transition of 1989, building the organizational system of the judiciary and guaranteeing judicial independence were essential issues as the operation of the socialist court system was reorganized. Judicial independence became the crucial principle of court activity. The rule of law was promoted by the 1989 complete revision of Act XX of 1949 on the Constitution. Judicial independence was interpreted as an institutional and a personal goal within this new rule of law framework.

According to the "1989 Democratic Constitution of the Hungarian Republic," the judiciary is a separate branch of power, independent of the other two traditional branches, the legislative and the executive. The courts act independently; no other body can supervise their jurisprudence. Judges must be independent and only subordinated to laws, and they cannot be instructed concerning their judicial activities. Besides, judges may only be removed from office for certain reasons and in a procedure specified by law. Judges may not be members of political parties or engage in political activities. In addition, the appointment procedure is also a constitutional guarantee of judicial independence, as only the President of the State may appoint the judges.

After the democratic transition, the Hungarian Constitutional Court declared that the judiciary, contrary to the other two "political" powers, is stable and neutral. ${ }^{55}$ It is also an absolute requirement that judicial adjudication is independent of any external influence, and is under an absolute constitutional protection. ${ }^{56}$ However, judicial independence does not mean unlimited judicial power, as the courts are also subject to the law. ${ }^{57}$ The courts' exclusive power to decide on litigation includes their duty to provide legal protection to the parties in cases that fall to their jurisdiction. Creation of the National Council of Justice can be mentioned here as an important milestone in court administration.

\section{The 2011 Judicial Reform and Failed Attempts at Legislative Influence}

In 2010, when the Fidesz-KDNP party coalition won a two-thirds majority in Parliament, the Hungarian judiciary reform started again. Before 2012, the National Council of Justice, as a self-governing body, was charged with the administration of the courts. Claiming that the old institution was slow and nepotistic, the new regulation, founded in the Fundamental Law, introduced new institutions.

\footnotetext{
${ }^{53}$ For example, Gábor Attila Tóth, Constitutional Markers of Authoritarianism, 11 HaGUe J. RULE LAW 37, 37-61 (2019); Gábor Halmai, Populism, Authoritarianism and Constitutionalism, 20 GER. L.J. 296, 296-313 (2019); Tímea Drinóczi \& Agnieszka Bień-Kacała, Illiberal Constitutionalism: The Case of Hungary and Poland, 20 German L.J. 1141, 1148 (2019).

${ }^{54}$ See a basic description of the Hungarian judiciary in English that I cite and follow in this section in ZOLTÁN SZENTE, Constitutional LAW IN HUnGary 200-13 (2d ed. 2021). I will also use some parts of my former study on the 2011 judicial reform, Fruzsina GÁRdos-Orosz, The appointment and removal of judges in Hungary - efforts, reforms and constiutional controversies, PrZeglad Prawa Konstytucyjnego 81 (2015)

${ }^{55}$ Alkotmánybíróság (AB) [Constitutional Court] June 11, 1993, AK. Decision 39/1993. (VI. 11.) (Hung.).

${ }^{56}$ Alkotmánybíróság (AB) [Constitutional Court] March 29, 1994, AK. Decision 17/1994. (III. 29.) (Hung.).

${ }^{57}$ Alkotmánybíróság (AB) [Constitutional Court] June 25, 1999, AK. Decision 19/1999. (VI. 25.) (Hung.).
} 
Between 2010 and 2012, the government gradually altered the whole judicial system. The most important sources of the legal status of the courts include the chapter on Courts, Articles 25-28 of the Fundamental Law of Hungary - the constitution-of 2011, the Act CLXI of 2011 on the Organization and Administration of Courts, and the Act CLXII of 2011 on the Legal Status and Remuneration of Judges. Courts administer justice, decide on criminal matters, civil and administrative disputes, and other matters specified by law. These reforms focused on creating a more centralized and accountable administration of justice by establishing a more efficient and faster judicial activity. ${ }^{58}$ Central to the judicial reform was the thorough modification of the processes of selection, discipline, and unsuitability for office proceedings. Even though the reforms of 2010-2012 changed the situation of judges in many respects, as was the case with the selection and removal of judges, the protection of independence and professionalism seemed to be a primary goal of the changes. ${ }^{59}$

The result of the new codification, however, was contestable in many regards. Three leading NGOs (non-governmental organizations) summarized that:

[W] hile the deficiency of the former model of administration was that judicial independence was placed before any other interest, the new administrative model, and the one-person decision-making mechanism, directly threatens the formerly protected judicial independence. ${ }^{60}$

The Venice Commission also argued that the President of the National Office of the Judiciary has uncontrolled competencies pursuant to the law. ${ }^{61}$ Following the national and international criticism of many provisions of the acts of Parliament on courts, judges, and the prosecution office in Hungary, implemented in 2011 and entered into force at the beginning of 2012, specific provisions of the Act were amended and the appointment of judges was no longer solely in the hands of the President of the National Office of the Judiciary.

The President of the National Office of the Judiciary further performs tasks of the central administration of courts. To ensure operational efficiency, the President was vested with extensive duties and responsibilities for the central administration. ${ }^{62}$ Among others, under Article 76 of the Act on the administration of courts, in his/her role regarding matters of human resources, the President publishes vacancies for judges, puts forward proposals to the President of the Republic concerning the appointment and removal of judges, and nominates judges. The President may adopt a decision on the transfer of the judge. The judge's posting to another place of service, decides, furthermore, whether or not the court's territorial jurisdiction has diminished to the degree that makes the judge's further employment there impossible, and many other important matters, almost all of which are related to significant administrative issues, are decided too. The system became centralized. The heads of the upper appellate courts, appointed by the President of the National Office have further tools in organizational matters but these are much less significant than they were.

The National Judicial Council also plays a vital role in the procedure for the appointment of judges, although a much less important role than the President of the National Office of the

\footnotetext{
${ }^{58}$ András Osztovits, The New Organizational System of the Hungarian Courts, in ThE Transformation OF THE Hungarian Legal System 2010-2013 131, 131-44 (Péter Smuk ed., 2013).

${ }^{59}$ Balázs Fekete, How to Become a Judge in Hungary? From the Professionalism of the Judiciary to the Political Ties of the Constitutional Court, in Fair Reflection of the SOCIETy IN Judicial Systems: A Comparative ANALYsis 169, $169-86$ (Sophie Turenne ed., 2015).

${ }^{60}$ Hungarian Helsinki Committee, Eötvös Károly Policy Institute \& Hungarian Civil Liberties Union, Opinion on the Acts of Parliament on Courts, Judges and the Prosecution Service in Hungary (2012).

${ }^{61}$ Eur. Consult. Ass., Opinion 663/2012 of the Venice Commission on Act CLXII of 2011 on the Legal Status and Remuneration of Judges, 90th Sess., No. 7-18 (2012).

${ }^{62} 2011$. évi CLXI. törvény a bíróságok szervezetéről és igazgatásáról (Act CLXI of 2011 on the organization and administration of courts) (Hung.).
} 
Judiciary. The Council comprises fifteen members elected by a council of the representatives of the Hungarian courts. This body should advise and approve the decisions of the President of the National Judicial Office, but its consent is not necessary for the decision.

Lastly, due to their role in the selection procedure, the so-called judicial boards must be mentioned. These boards are responsible for the preparation of the decision. Each regional court must elect a self-governing body. These boards are elected by the regional council of judges, which have five to fifteen members. ${ }^{63}$ One of their primary duties is to participate in the appointment process by interviewing applicants and make rankings, but compared to the former legislation, they lost most of their competence apart from this task.

Despite the detailed regulation of the court system's administration and the selection of judges, several controversial issues have emerged in recent years in Hungary. ${ }^{64}$ Apart from the concerns related to the extraordinary competence of the President of the National Office of the Judiciary in the administration, which necessarily influences indirectly the independence of the adjudication activity, constitutional concerns were raised in a case related to the socialist past as well.

The new Government, with the two-thirds majority constitution-making power, wanted to break with the past, which in practical terms meant dismissing the judges who were socialized in the socialist period before the democratic transition of 1989. The new parliamentary majority soon decided on the forced retirement of judges at the age of sixty-two ${ }^{65}$ Consequently, this meant that suddenly more than 200 judges lost their positions, most of whom were in leading roles. On July 16, 2012, the Hungarian Constitutional Court ${ }^{66}$ declared that implementing provisions relating to judges' retirement age was unconstitutional. However, that ruling did not reinstate the retired judges to their former positions as most of these positions had already been taken by the decision date. The Constitutional Court stated that Section 230 of Act CLXII of 2011 on the legal status and remuneration of judges was unconstitutional. Therefore, the Constitutional Court struck down this section retroactively, as of January 1, 2012. The Constitutional Court emphasized the necessity and importance of the independence of judges in this decision. Under the Fundamental Law of Hungary, the judge's independence is the most important guarantee of the autonomous application of law. One element of the independence of judges is personal independence. This means that the judge may not be ordered to step down and may not be removed against her/his will. In other words, the appointment of a judge is for life. The independence of the judge requires several guarantees from other branches of the government.

The Constitutional Court determined in this case that the Fundamental Law of Hungary did not include the age of retirement. Act CLXII of 2011, on the legal status and the remuneration of judges, did not regulate retirement age either. The phrase in the legal text indicating the "average age of retirement" ${ }^{\prime 67}$ did not entail a precise legal definition due to the continuous transformation of the retirement system. However, for judges, the upper age limit of retirement had been seventy years old for more than a century, ${ }^{68}$ and it was seventy when the Fundamental Law of Hungary came into force in 2012. Judges older than sixty were responsible for deciding many cases. To take these cases from them-as the Constitutional Court argued-contradicted the general principle that judges cannot be disengaged from cases unless there was an exceptional circumstance. The argument from constitutional tradition was decisive in this case. This entailed a reference to the

\footnotetext{
${ }^{63}$ 2011. évi CLXI. törvény a bíróságok szervezetéröl és igazgatásáról (Act CLXI of 2011 on the organization and administration of courts) (Hung.).

${ }^{64}$ András Jakab, Informal Elements as Both Preconditions and Consequesnces of Effective Formal Rule: The Failure of Constitutional Institution Building in Hungary, 68 AM. J. COMP. L. 760, 760-800 (2020).

${ }^{65}$ Gábor Halmai, The Early Retirement of the Hungarian Judges, in EU LAW STORIES: CONTEXTUAL AND CRITICAL Histories of EuropeAn JurisprudenCE 471, 471-488 (Fernanda Nicola \& Bill Davies eds., 2017).

${ }^{66}$ Alkotmánybíróság (AB) [Constitutional Court] July 17, 2012, AK. Decision 33/2012. (VII. 17.) (Hung.).

${ }^{67}$ 2011. évi CLXI. törvény a bíróságok szervezetéről és igazgatásáról (Act CLXI of 2011 on the organization and administration of courts) (Hung.).

${ }^{68}$ Since 1869. See Alkotmánybíróság (AB) [Constitutional Court] July 17, 2012, AK. Decision 33/2012. (VII. 17.) (Hung.)
} 
historical constitution in one of the concurring opinions and an interpretation of the doctrine of "legitimate expectation" that otherwise did not exist in this form in the Hungarian jurisprudence.

Furthermore, the European Commission of Democracy through Law stated that although the legislator claimed that these provisions are "just transitional with a view to the reduction of the upper age limit to sixty years and shall allow for a smooth and gradual retirement," the provisions' transitional character is not stipulated in the Law, and it is difficult to find any justification for why judges especially need a "smooth and gradual retirement" by exempting them from office." ${ }^{\text {" After }}$ the Hungarian Constitutional Court's decision, the Opinion of the Venice Commission of the Council of Europe of October 15, 2012 called upon the Hungarian legislator to adopt provisions reinstating the dismissed judges to their previous positions without requiring them to go through a reappointment procedure. $^{70}$

The European Court of Justice found in the same case a violation of EU law. At the European Commission's request, the Court of Justice of the European Union ruled that the radical lowering of the retirement age for judges, prosecutors, and notaries in Hungary violated EU equal treatment rules. ${ }^{71}$ According to the Court's judgment, the forced early retirement of hundreds of judges in 2012 constitutes unjustified age discrimination. ${ }^{72}$

The EU Court of Justice did not find any objective justification for the drastic lowering of the age limit of judges. Besides, in view of the brief transitional period for such an extensive reform and the contradiction of first drastically lowering the age limit before raising it again in 2014, the European Court of Justice found the measure disproportionate, and therefore not in compliance with Directive 2000/78/EC. ${ }^{73}$

The above case involving the forced retirement of judges is a good example to illustrate the relationship between the present and the past. From the institutional perspective, the State wished to have a purged judiciary, although the democratic transition was based on legal continuity and the lack of lustration laws. This decision on continuity meant that the independent judiciary personnel remained in position due to the recognition of their former independence. Yet, the method of introducing a change to the composition of the personnel of an independent constitutional institution, the judiciary, failed in legal terms, although in practice most of the judges could not or did not want to claim their actual position back after the long judicial procedure.

The attempts at influence were harmful in the long run, not only because of their immediate and actual results, but also because of the uncertainty they caused. Judges currently in office must bear in mind that even if their status is secured, the constitution and the cardinal laws may be easily amended by the votes of a two-thirds majority. Change comes from one day to the next and can unforeseeably threaten the status of individual judges and the organization as well. ${ }^{74}$

As many of the legislative and constitutional attempts to put institutional pressure on the judiciary and its daily operation have failed in recent years, partly due to international and EU concerns, the ruling majority have introduced other ideas to emphasize the necessity of change in the new political regime. I consider the role of the concept of the constitutional identity in the last section.

\footnotetext{
${ }^{69}$ Eur. Consult. Ass., Opinion 663/2012 of the Venice Commission of March 2012 on Act CLXII of 2011 on the Legal Status and Remuneration of Judges, 90th Sess., No. 25-6 (2012).

${ }^{70}$ Eur. Consult. Ass., Opinion 683/2012 of the Venice Commission of October 2012 on the Cardinal Acts on the Judiciary that were Amended, 92nd Sess., No. 20 (2012).

${ }^{71}$ Directive 2000/78/EC, of the European Parliament and of the Council of 27 November 2000 establishing a general framework for equal treatment in employment and occupation 2000/78/EC, 2000 O.J. (L 303) 16-22.

${ }^{72}$ Case C-286/12, Comm'n v. Hungary, ECLI:EU:C:2012:687, (Nov. 6, 2012).

${ }^{73}$ Miklós Kocsis, Az európai biróság itélete a birák nyugdíjazása ügyében, 4 KöZJOGI SzEMLE 71, 71-72 (2012).

${ }^{74}$ Mátyás Bencze, A bírósági rendszer átalakításának értékelése, 41 MTA LAW WORKING PAPERs 2, 2-11 (2014).
} 


\section{An Influential Concept: Constitutional Identity and its Role in Ordinary Jurisprudence}

In Decision 22/2016 (XII. 5.), ${ }^{75}$ the interpretation of the Fundamental Law had been requested from the Constitutional Court by the ombudsman. As explained in the motion, the concrete constitutional issue was related to European Union Council Decision (EU) 2015/1601 of September 22, 2015 on migration, but the ombudsman initiated the authoritative interpretation of Article E) of the Fundamental Law related to the accession to and cooperation with the EU. In this decision, the Constitutional Court developed the notion of constitutional identity to identify the particular approach of the Hungarian State to constitutional rights and values and to the rule of law. The concept of constitutional identity had not thus far been present in any domestic legal text. Significantly, the case was decided at a moment when the Government had already failed to get through a constitutional amendment with similar content, because in those months it did not have the two-thirds majority in Parliament, and an attempt to incorporate such a rule by a referendum had also failed. ${ }^{76}$

The Constitutional Court stated that the EU provides adequate protection for fundamental rights. The Constitutional Court, however, cannot set aside the protection of domestic fundamental rights, and it must grant that the joint exercise of competences with the EU would not result in a violation of human dignity as protected by the Hungarian Fundamental Law or the essential content of other fundamental rights. The Court set two main limitations in the context of the question regarding the legal acts of the Union that extend beyond the jointly exercised competencies. First, the joint exercise of competence cannot violate Hungary's sovereignty. Second, it cannot lead to the violation of its constitutional identity. The Constitutional Court emphasized that the protection of constitutional identity should take the form of a constitutional dialogue based on the principles of equality and collegiality, implemented with mutual respect.

The Constitutional Court of Hungary interpreted the concept of constitutional identity as Hungary's self-identity, and according to the decision, it will unfold the content of this concept from case to case, based on the whole Fundamental Law and specific provisions thereof, following the National Avowal and the achievements of our historical constitution - as required by Article R) (3) of the Fundamental Law.

This decision was overwhelmingly criticized in constitutional scholarship because of its arbitrariness. ${ }^{77}$ I argue here shortly, without discussing the decision on the merits, that this new substantive concept of constitutional identity-even if it exists in many other jurisdictions ${ }^{78}$-was developed in Hungary in line with populist political goals ${ }^{79}$ because it serves as a basis for protective national constitutionalism against $\mathrm{EU}$ or international legislation, which is considered to be elitist, internationalist, pluralist, liberal, and pro-migration, according to existing political communications. ${ }^{80}$ Proof of this argument is that as soon as the Government majority in Parliament regained its two-thirds constitution-amending majority, Parliament added the notion of constitutional identity to the Fundamental Law's text ${ }^{81}$ in Article R), with the Seventh

\footnotetext{
${ }^{75}$ Alkotmánybíróság (AB) [Constitutional Court] Dec. 5, 2016, Decision 22/2016 (XII. 5.) (Hung.), referred to throughout this section.

${ }^{76}$ Zoltán Szente, The Controversial Anti-Migrant Referendum in Hungary is Invalid, CONSTITUTION-MAKING AND Constitutional Change Blog by the Research Group of the IACL (Oct. 11, 2016), https://constitutional-change. $\mathrm{com} / \mathrm{tag} /$ invalid-referendum/.

${ }^{77}$ E.g., Gábor Halmai, National(ist) Constitutional Identity? Hungary's Road to Abuse Constitutional Pluralism 1, 1-16 (European University Institute Law, Worki, 2017); Tímea Drinóczi, The Constitutional Identity in Europe, The Identity of Constitution, a Regional Approach, 21 German L.J. 105, 105-30 (2020).

${ }^{78}$ The German jurisprudence, for example, is famous for its protectionist approach, see the new PSPP decision. BVerfG, 2 BvR 859/15, May 5, 2020, https://www.bundesverfassungsgericht.de/SharedDocs/Entscheidungen/EN/2020/05/rs20200505_ 2bvr085915en.html.

${ }^{79}$ Nóra Chronowski \& Attila Vincze, Önazonosság és európai integráció, 72 JogTUdOMÁNYI KöZlÖNY 117, 117-32 (2017).

${ }^{80}$ Even if the intent of some members of the Constitutional Court was to create a constitutional conversation with the concept. Tamás Sulyok \& Gergely Deli, A magyar nemzeti identitás az Alkotmánybiróság gyakorlatában, 2 AlKotMÁNYbírósági SZEMLE, 45, 45-67 (2019).

${ }^{81}$ Magyarország Alaptörvénye [The Fundamental Law of Hungary], Alaptörvény. Referred to throughout this section.
} 
Amendment to the Fundamental Law in 2018. According to Article R) 4 (4): “The protection of the constitutional identity and Christian culture of Hungary shall be an obligation of every organ of the State."

With this step, the constitutional identity concept gained relevance not only in terms of international cooperation but also of the domestic understanding of the law. Article R) contains provisions on the required methods of interpretation of the Fundamental Law. This approach opens an uncertain, case-by-case interpretation of a central substantive concept related to the interpretation of all the other Fundamental Law provisions.

Furthermore, with the Seventh Amendment to the Fundamental Law, the notion of constitutional identity gained further relevance in the daily interpretation of the ordinary law. In the preamble of the Fundamental Law, the National Avowal, we can read: "We hold that the protection of our identity rooted in our historic constitution is a fundamental obligation of the State." According to Article 28 of the Fundamental Law:

In the course of applying the law, ordinary courts shall interpret the text of laws primarily per their purpose and with the Fundamental Law. In the course of ascertaining the purpose of a law, consideration shall be given primarily to the preamble of that law and the justification of the proposal for the law or amendment. When interpreting the Fundamental Law or laws, it shall be presumed that they serve moral and economic purposes which are [in accordance with] common sense and the public good.

The Constitutional Court can review the judicial decision in the German-type constitutional complaint of the Article 24 (2) d), procedures provided by the Fundamental Law. Therefore, the application of Article 28, the assessment of the Fundamental Law, and the decisions of the Constitutional Court became an obligation for the courts.

This means that during this period in Hungary, the ruling political power created a legal framework where the influence on the daily work of the judiciary is influenced through new concepts implemented by the Fundamental Law and other laws that can be unilaterally changed by the same two-thirds majority sitting in Parliament since 2010, and controlled by the Constitutional Court whose fifteen members were elected by this parliamentary majority. ${ }^{82}$ Just like the content of constitutional identity, the requirement it poses is formed openly on a case by case basis, and it is the fifteen member Constitutional Court that can decide, even in a five member panel, on decisions in constitutional complaint cases about the obligatory interpretation of one or the other legal provision. ${ }^{83}$

Constitutional identity is therefore a new concept that suggests a divergence from the Western type, common EU, and international rule of law standards. Constitutional identity emphasizes national particularities and specificities, while creating pressure on the ordinary judiciary when taking seriously the requirement to conform with a constitutional concept that is uncertain and determined unilaterally by the Government majority and by the members of the Constitutional Court elected by this majority. If the judiciary does not conform to this, the decision can be annulled.

\section{Comparative Conclusion}

In this Article, I have compared two periods of the legal system, the Socialist Hungary and the illiberal constitutional regime after 2012, that seem to be very different. In these two periods, rule

\footnotetext{
${ }^{82}$ Zoltán Szente, The Political Orientation of the Members of the Hungarian Constitutional Court Between 2010 and 2014,1 Const. STUd. 123, 123-149 (2016).

${ }^{83}$ See new cases on freedom of expression: CONSTITUTIONAL COURT OF HUNGary, The Expression of Opinion is Free, the Dividing Line is the Protection of Human Dignity, (Feb. 5, 20210), http://hunconcourt.hu/announcement/the-expression-ofopinion-is-free-the-dividing-line-is-the-protection-of-human-dignity.
} 
of law concerns were raised, and particular understandings of the law and justice were formulated. The judiciary is the primary state institution or branch of power responsible for enforcing the law in disputes. Therefore, I have focused on the legal environment of the judiciary in both periods in order to understand the constraints on the interpretation and the application of the law in a state in which one political party rules with a constitution-making majority. To understand the particular approach to the rules of the law and the role of the judiciary, I examined the concepts that underlie this special approach to the rules of law, and I examined how the new concepts were realized in the legal environment. The legislation on the court system, the status of the judges, other formalized and non-formalized ways of negotiations, and review allowed us to understand the nature, or perhaps the limits, of the independence of the judiciary in the two periods.

I have argued that although the new Hungarian Fundamental Law in Article U) rejects any relationship with the Socialist past, there are fundamental attitudes towards law and justice that appear to be similar in the two eras. I have argued that general concepts such as socialist legality and constitutional identity influence the entire legal order, and that constitutional interpretation and legislative and judicial work equally. Furthermore, this political approach leads to similar uncertainties in interpretation on a daily basis, and thus room for sliding influence. This legal atmosphere results in an unceasing judicial search for the proper interpretation of the law, which is not defined a priori and concretely by law, and cannot be revealed by any common methods of legal interpretation.

The similarity between the two periods examined lies much more in the uncertainty of the due application of the law by the introduction of the new concepts than in the institutional design itself. What is also similar, however, is that formal influence on daily judicial work is rare; even the institutional impacts are designed to be somewhat hidden and not straightforward. I have explained that compared to 1953, the end of Stalinism brought significant attempts to guarantee some independence to the judiciary. However, it was different from the "bourgeois rule of law" standards; the limits of independence were framed abstractly, partly by the concept of socialist legality.

Moreover, we have seen that since 2011, Hungary has claimed to create guarantees of independence. Although there have been several attempts at direct intrusion in the operation of administrative matters, several of these attempts have failed because of constitutional, interpretational, and EU law constraints.

Let us suppose that the concept of legality is determined in law by externally introduced factors such as compulsory quasi-judicial concepts that alter legality to conform with the new standards. In this case, the atmosphere of uncertainty becomes a stress in a judge's daily work, and a transformative atmosphere rules when applying the law.

In Marxism, this serves as a basis for socialist legalism because the final goal is to criticize liberal political philosophy. ${ }^{84}$ The judiciary's independence is a central element of the bourgeois or western type rule of law concept as the judiciary is responsible for imposing restraint on power and limiting the Government. If the Government does not intend to be limited, as is the case in the two periods of Hungarian history I have examined, the judiciary needs to be captured. It can be captured by administrative rules of discipline, appointment, removal, instruction, and new quasi and supra legal concepts that are compulsory for interpreting the law. I have explained that socialist legality and constitutional identity, as employed by the new constitutional regime in Hungary, are similar in nature and similar in their functions in their particular legal environments. Both are instrumental in creating a particular understating of the rule of law to enforce socialism and

\footnotetext{
${ }^{84}$ Martin Krygier, Marxism and the Rule of Law: Reflections After the Collapse of Communism, 15 LAW \& SOC. INQUIRY 652, 652 (1990).
} 
illiberalism. Socialist legality as regards legality, and illiberal constitutionalism as regards constitutionalism, are similar political ideas, and both instrumentalize law and deprive it of the autonomous nature that makes it capable of limiting the governing power. Path dependency might indicate that the general acceptance and obedience to this new constitutional idea in 2021 in Hungary is sociologically reasoned by the fact that the idea is, as I have shown, familiar to many of us who remember the times before the democratic change of 1989. 